\title{
India's Finance-Growth Nexus: Cointegration and Causality Analysis with Income Inequality and Globalization
}

\author{
Takashi Fukuda \\ Correspondence: Takashi Fukuda, Independent researcher, 5-15-81-401, Toroku, Chuou-ku, Kumamoto, 862-0970, \\ Japan
}

Received: August 1, 2018

doi:10.11114/aef.v5i6.3502
Accepted: September 14, $2018 \quad$ Available online: September 25, 2018

URL: https://doi.org/10.11114/aef.v5i6.3502

\begin{abstract}
This paper investigates India's finance-growth nexus-the relationship between financial development and economic growth - taking the weakly exogenous variables of income inequality, trade openness and financial openness together with the structural break dummy into the cointegration analysis of the vector error correction model. Implementing the Granger causality tests we have detected that both financial size and financial efficiency exhibit a negative impact on economic growth with no feedback from the latter to each of the former. It is important for policy makers to recognize that finance does not always promote economic growth, considering how to convert the effect of financial development from "growth-retarding" to "growth-enhancing".
\end{abstract}

Keywords: India, finance-growth nexus, income inequality, globalization, cointegration, VECM

\section{Introduction}

Since Schumpeter (1911) argued that a well-developed financial system is important to attain higher economic growth through technological innovations, the topic of the finance-growth nexus-how finance and growth influence each other-has been extensively investigated in the literature; a well-developed financial system is considered as essential for economic growth by channeling financial resources to most productive uses. While several empirical studies have been conducted for the relationship between economic growth and financial development, there is a controversy between cross-country studies (e.g. King and Levine 1993; Levine and Zervos 1998) and time series ones (e.g. Demetriades \& Hussien, 1996; Luintel and Khan, 1999). To consider the finance-growth nexus more precisely, the present paper focuses on the issue of Patrick (1966) who put forth the hypothese of the "supply-leading" and "demand-following" arguing that the causal relationship between economic growth and financial development can exhibit different directions throughout the development process.

According to the supply-leading hypothesis, financial development can facilitate an economy to grow by transferring funds from traditional (non-growth) sectors to modern ones and by stimulating an entrepreneurial response in the latter. So the direction given by the supply-leading hypothesis is "finance $\rightarrow$ growth". Such economists as McKinnon (1973) and Shaw (1973) support the supply-leading hypothesis arguing that financial development is a necessary condition for achieving high rate of economic growth. Especially, the two authors are in favour of liberalizing the financial system while criticizing such financial repression policies as ceilings on interest rates, high reserve requirements and administrative credit allocation. On the other hand, the demand-following hypothesis implies that financial development is a phenomenon in response to the demand for financial services; as an economy grows, such a demand will spontaneously increase and result in the evolution of the financial system. As Robinson (1952) argued that 'where enterprise leads finance follows', the expected direction is "growth $\rightarrow$ finance". Furthermore, we can also assume the two-way relationship where financial development and economic growth have an impact on each other (finance $\leftrightarrow$ growth); a well-developed system is essential for economic growth, whereas the latter is also necessary for the former as financial markets effectively respond to the demand for certain financial instruments and arrangements which are created by economic expansion ${ }^{1}$.

The objective of the present study is to shed light on the "Patrick (1966) "issue-a kind of the "whether the chicken or the egg" debate-by analyzing the relationship between financial development and economic growth in India for the period 1951-2011 ${ }^{2}$. India is a good sample country for this research topic as it has a rich history of economic development as well as good, continuous date series. On the other hand, although several studies investigated India's 
finance-growth nexus, there is no consensus, that is, either supply-leading, demand-following or bilateral (see Demetriades \& Hussien, 1996; Luintel \& Khan, 1999; Bhattacharya \& Sivasubramanian, 2003; Fase \& Abma, 2003; Rousseau \& Vuthipadadorn, 2005; Katircioglu, Kahyar, \& Benar 2007; Singh, 2008; Fukuda, 2012).

This study contributes to the literature by addressing the following issue. As far as time series studies-their main interest is in exploring the Granger causality between financial and output variables-are concerned, since the use of a bivariate causality analysis was standard, earlier studies of two variables-finance and growth only-were more likely to suffer from the omission-of-variable bias. It is believed that other variables are likely to have great impact on the causal linkage; the absence of those variables in estimation would lead to the loss of vital information to accurately understand the relationship between financial development and economic growth (Enisan \& Olufisayo, 2009; Ibrahim, Abdullahi, Azman-Aaini, \& Rahman, 2017). Therefore, in order for avoiding misspecification, it has become standard to take various third and more variables into estimation. In this regards, we are concerned with whether/how income inequality and globalization influence India's finance-growth nexus.

The effect of financial development on income inequality through economic growth/improved access to finance has been increasingly examined in the literature (Ang, 2010; Sehrawat \& Giri, 2015; Tiwari, Shahbaz, \& Islam, 2013). As far as India is concerned, how the gains of economic growth are equally distributed is always one of important policy issues to achieve "social justice" in the country. It is widely known that a chronical inequality-rooted to various historical and social reasons-is observed in India; although numerous efforts have been made since the independence of 1947, the access to finance by the poor who indigenously lack resources to fund themselves is very limited. Hence, the topic of which classes are benefited from an increase in national income always economically and politically matters, strongly influencing policy decisions in India. On the other hand, the role of globalization has been emphasized for economic growth in developing countries. Globalization is considered as an effective tool for higher economic growth, contributing to the creation of more trade and investment opportunities. Nowadays most of developing countries have engaged in the rapid pace of globalization in various fields, following the recommendations from such international institutions as the World Bank and the IMF. In case of India, liberalization was initiated by opening up its goods and financial markets after the country was severely hit by a financial crisis in 1991. Since then, India has been regarded as an emerging economy attaining high GDP growth rates. Based on the above arguments, we contend that there is a need to incorporate the elements of income inequality and globalization into the analysis of India's finance-growth nexus because it is likely to give us interesting and plausible estimates, reflecting India's current situation more precisely.

In addition, we highlight the issue of measuring the extent of financial development. Most of empirical studies of the finance-growth nexus have employed the size-based financial indicators as more credit and funding are regarded to directly link to more financial deepening. However, it is questioned whether those size-based indexes, which are measured by the ratio of total domestic credit or various monetary aggregates to nominal GDP, are not perfect to proxy for the influence of financial development (Wachtel, 2011). This argument urges us to consider a qualitative aspect of financial development-in addition to a quantitative one-for analyzing India's finance-growth nexus.

The rest of the paper is organized as follows. The empirical strategy and data are provided in Section 2, and methodology is elucidated in Section 3. Empirical findings are presented and discussed in Section 4, and conclusion comes in Section 5.

\section{Empirical Strategy and Data}

We investigate India's finance-growth nexus by estimating two systems whose underlying variables are elucidated in Appendix A. To begin with, the first system explores the Granger causality between the economic growth index (= real per capita GDP, EG) and the financial size index (FS):

$$
\begin{aligned}
& E G_{t}=f_{1}\left(F S_{t}, G I N I_{t}, T O P_{t}, F O P_{t}\right) \\
& F S_{t}=f_{2}\left(E G_{t}, G I N I_{t}, T O P_{t}, F O P_{t}\right)
\end{aligned}
$$

Equations 1 and 2 answer the question of whether/how financial size and economic growth Granger-cause each other, that is, the causality runs either FS $\rightarrow \mathrm{EG}$ or $\mathrm{EG} \rightarrow \mathrm{FS}$ or $\mathrm{FS} \leftrightarrow \mathrm{EG}$. As a quantitative measure of financial development, we compute the financial size index with the ratio of commercial bank credit to the private sector divided by GDP. On the other hand, the second system investigates the Granger causality between the economic growth index and the financial efficiency index (FE):

$$
\begin{aligned}
& E G_{t}=f_{3}\left(F E_{t}, G I N I_{t}, T O P_{t}, F O P_{t}\right)
\end{aligned}
$$

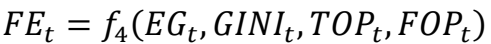

Equations 3 and 4 look for the causality of either $\mathrm{FE} \rightarrow \mathrm{EG}$ or $\mathrm{EG} \rightarrow \mathrm{FE}$ or $\mathrm{FE} \leftrightarrow \mathrm{EG}$, that is, whether/how financial efficiency and economic growth Granger-cause each other. As a qualitative measure of financial development, the financial efficiency index is given by the ratio of commercial bank credit to the private sector divided by the total 
domestic deposit (demand deposit + time deposit) (Beck, Demirgüç-Kunt, \& Levine, 2009) ${ }^{3}$. By using these two indexes, we do not have the imbalanced representation of certain aspects of financial development (Gries, Kraft, \& Meierrieks, 2009).

More importantly, in order to avoid the omission-of-variable bias in the analysis, we include such weakly exogenous variables as the Gini coefficient (GINI), the trade openness index (TOP) and the financial openness index (FOP). The Gini coefficient is the most commonly used indicator of income distribution ranging between zero (absolute equality) and one (absolute inequality). While the Gini coefficients of many countries are less available or have several missing values, India provides a relatively good and continuous data series. As far as globalization is concerned, we consider incorporating two indexes. First, following the standard procedure in the literature, we make the trade openness index-the proxy for the external openness of the goods market—with India's trade volume (exports + imports) divided by GDP. Second, based on the argument of Lane and Milesi-Ferretti (2007), the financial openness index-a composite indicator for the external openness of the financial market-is produced by combining the two elementary variables of: i) foreign exchange reserve, and ii) net foreign assets held by commercial banks; these two elementary variables are deflated by GDP and composited through the principal component method to create a single indicator while avoiding the imbalanced representation of India's financial openness (for the detail, see Appendix B). All the underlying and weakly exogenous variables are converted into logarithm. For this study we employ annual observations-drawn from IMF's International Financial Statistics (IFS) online database-ranging from 1951 to 2011, which is a fairly long time span to ensure the quality of the estimation. The series of India's Gini coefficients is extracted from the latest versions of UNU-WIDER's World Income Inequality Database and the World Bank's Databank. Finally, Table 1 reports the correlations between the underlying variables. The statistics show that EG and FS are positively correlated at the 1\% significance level. On the other hand, EG and FE are negatively correlated at the 5\% significance level. And the correlation between FS and FE are statistically insignificant, indicating different evolutions of India's financial development.

Table 1. Correlations between the underlying variables

\begin{tabular}{lllllll}
\hline & EG & FS & FE & GINI & TOP & FOP \\
\hline EG & 1 & & & & & \\
FS & $0.903^{* * *}$ & 1 & & & & \\
FE & $-0.311^{* *}$ & -0.111 & 1 & & & \\
GINI & -0.037 & -0.173 & $-0.408^{* * *}$ & 1 & & \\
TOP & $0.871^{* * *}$ & $0.710^{* * *}$ & $-0.470^{* * *}$ & $0.294^{* *}$ & 1 & \\
FOP & $0.285^{* *}$ & 0.026 & $-0.544^{* * *}$ & $0.692^{* * *}$ & $0.600^{* * *}$ & 1 \\
\hline
\end{tabular}

Notes: $(* * *) 1 \%$ and $(* *) 5 \%$ level of significance.

\section{Methodology}

As Engle and Granger (1987) argue that a vector autoregression (VAR) process should be estimated in terms of dynamic adjustment, we adopt the cointegration and vector error correction model (VECM) suggested by Johansen (1988) so as to examine India's finance-growth nexus. One advantage of the approach is that it presents a definite causal direction with the sign of each underlying variable's coefficient in the cointegrating space. Another one is that it enables us to treat some underlying variables as weakly exogenous variables-but not as endogenous variables-in the cointegrating space. Based on these arguments, the following model specification is given:

$$
X_{t}=\Pi Y_{t-p}+\Gamma_{1} \Delta Y_{t-1}+\Gamma_{2} \Delta Y_{t-2}+\cdots+\Gamma_{p-1} \Delta Y_{t-p+1}+u_{t}
$$

In equation $5, X_{t}=[\mathrm{EG}, \mathrm{FS} / \mathrm{FE}]$ is a $2 \times 1$ vector of the endogenous/dependent variables; $Y_{t}=[\mathrm{EG}, \mathrm{FS} / \mathrm{FE}, \mathrm{GINI}, \mathrm{TOP}$, FOP] is the cointegrating vector of the endogenous and weakly exogenous variables; $p$ is the lag order included in the system; $\Gamma_{i}$ refers to short-run coefficient matrices; and $u_{t}$ is a vector of error terms. The long-run relationship between the endogenous/dependent variables is represented by the rank of $\Pi$ matrix $(r)$ where $0<r<2$. The two matrices $\alpha$ and $\beta$ with dimension $(2 \times r)$ are given with $\alpha \beta=\Pi$. The matrix $\beta$ contains the $r$ cointegrating vectors, holding the property that $\beta y_{t}$ is stationary. $\alpha$ is the matrix of the error correction presentation that measures the speed of adjustment from short-run disequilibrium to long-run steady state equilibrium.

Assuming a single cointegrating vector $(r=1)$ in the analysis, we first present the following 5 -variable system equation in which financial development is proxied by the financial size index: 


$$
\left[\begin{array}{l}
\Delta E G_{t} \\
\Delta F S_{t}
\end{array}\right]=\left[\begin{array}{l}
\alpha_{1 j} \\
\alpha_{2 j}
\end{array}\right]\left[\beta_{i 1} \beta_{i 2} \beta_{i 3} \beta_{i 4} \beta_{i 5}\right]\left[\begin{array}{c}
E G_{t-1} \\
F S_{t-1} \\
G I N I_{t-1} \\
T O P_{t-1} \\
F O P_{t-1}
\end{array}\right]+\Gamma_{i j}\left[\begin{array}{c}
\Delta E G_{t-p} \\
\Delta F S_{t-p} \\
\Delta G I N I_{t-p} \\
\Delta T O P_{t-p} \\
\Delta F O P_{t-1}
\end{array}\right]+\left[\begin{array}{l}
\hat{u}_{1 t} \\
\hat{u}_{2 t}
\end{array}\right]
$$

In equations (6), EG and FS are the endogenous/dependent variables, whereas GINI, TOP and FOP are weakly exogenous variables in the cointegrating vector. Likewise, the 5-variable system equation in which the financial efficiency index is employed-instead of the financial size index-is given as follows:

$$
\left[\begin{array}{l}
\Delta E G_{t} \\
\Delta F E_{t}
\end{array}\right]=\left[\begin{array}{l}
\alpha_{3 j} \\
\alpha_{4 j}
\end{array}\right]\left[\begin{array}{ll}
\beta_{i 6} \beta_{i 7} \beta_{i 8} \beta_{i 9} \beta_{i 10}
\end{array}\right]\left[\begin{array}{c}
E G_{t-1} \\
F E_{t-1} \\
G I N I_{t-1} \\
T O P_{t-1} \\
F O P_{t-1}
\end{array}\right]+\Gamma_{i j}\left[\begin{array}{c}
\Delta E G_{t-p} \\
\Delta F S_{t-p} \\
\Delta G I N I_{t-p} \\
\Delta T O P_{t-p} \\
\Delta F O P_{t-1}
\end{array}\right]+\left[\begin{array}{l}
\hat{u}_{3 t} \\
\hat{u}_{4 t}
\end{array}\right]
$$

Normalizing each of EG and FS/FE in equations 6 and 7, respectively, we conduct two types of the Granger causality test. The first test is the weak exogeneity test that imposes zero restrictions on $\alpha$, i.e. $H_{0}: \alpha_{i j}=0$; the rejection of the null hypothesis indicates that there is a long-run causality formed by all the underlying variables in the system (Johansen \& Juselius, 1992). The second one is the strong exogeneity test that imposes a restriction on both $\alpha$ and $\beta$, i.e. $H_{0}: \alpha_{i j} \beta_{i j}=0$ (Toda \& Phillips, 1993).

Moreover, referring to Johansen, Mosconi, and Nielsen (2000) who suggest techniques taking the element of structural break into the cointegration analysis, we take the structural break in economic growth dummy (SBGD) into the VECM assessment. The main reason why the dummy is incorporated is to seek a single cointegration $(\mathrm{r}=1)$ and no autocorrelation in estimation. To this end, structural break dates in India's EG (real per capita GDP) series are computed by the Lee and Strazicich $(2003 ; 2004)$ (hereafter the LS test). The LS test is a Lagrange multiplier unit root test that endogenously pinpoints at most two breaks in each series. Based on the break dates detected by the LS test in Table 2, we make eight break dummies - in the form of a break either in the level or in the trend-and allocate each of them in estimation. Among them, we confirm that the trend break dummy of 1991, whose date is detected by model C of the LS test, is optimal for estimating both the two models and so adopt it as the dummy ${ }^{4}$.

Table 2. Break dates in India's EG series

\begin{tabular}{ll}
\hline Model & Break date(s) \\
\hline A (one break) & 1978 \\
AA (two breaks) & $1966 ; 1978$ \\
C (one break) & 1991 \\
CC (two breaks) & $1972 ; 1995$ \\
\hline
\end{tabular}

Notes: Models A and AA $=$ the clash models (break(s) only in the intercept); Models $\mathrm{C}$ and $\mathrm{CC}=$ the trend break models (break(s) in both the intercept and trend).

\section{Empirical Findings}

\subsection{Initial Procedures}

The VECM cointegration analysis of India's finance-growth nexus is started with two unit root tests: the GLS augmented Dickey-Fuller (ADF-GLS) test (Elliott, Rothenberg, \& Stock, 1996) and the Phillips and Perron (PP) test (Phillips \& Perron, 1988) to identify the stationary property of each underlying variable ${ }^{5}$. Table 3 reports that almost all of EG, FS, FE, GINI, TOP and FOP are found out as non-stationary in their levels but become stationary after taking their first-differences at the $10 \%$ level or better. Specifically, referring to the "intercept and trend" results of the PP test, we conclude that all the underlying variables are adequate for the analysis.

Next, for seeking possible cointegration relationships, the cointegration test of Johansen (1988) is implemented at the lag order of two $(k=2)$ which is set by considering the sample period 1951 to 2011 (64 observations) of the present study. While GINI, TOP and FOP are treated as weakly exogenous variables, whereas both the dummy variable (SBGD) and a linear trend are included in the cointegrating vector. The trace statistics in Table 4 show that there is a single cointegration relationship $(r=1)$ at the $5 \%$ significance level in the two models, respectively ${ }^{6}$.

Before we discuss empirical findings, the results of the diagnostic tests are presented in Table 5. According to the 
statistics, the two model are free from all the problems of autocorrelation, non-normality and heteroscedasticity. Therefore, we contend that empirical findings of the present study are validated for analyzing India's finance-growth nexus.

Table 3. Unit root test results $(k=2)$

\begin{tabular}{lllll}
\hline & ADF Test & & $\underline{\text { PP Test }}$ & \\
& Inpt. & Inpt. \& trend & Inpt. & Inpt. \& trend \\
\hline EG & $3.982^{* * *}$ & 1.991 & $4.710^{* * *}$ & 2.015 \\
$\Delta$ EG & -2.519 & $-4.066^{* *}$ & $-6.752^{* * *}$ & $-8.176^{* * *}$ \\
FS & -1.493 & -2.032 & -0.685 & -1.838 \\
$\Delta$ FS & $-4.167 * * *$ & $-4.185^{* * *}$ & $-9.225 * * *$ & $-9.263^{* * *}$ \\
FE & -1.796 & -2.285 & -1.828 & -1.982 \\
$\Delta$ FE & $-5.575^{* * *}$ & $-5.626^{* * *}$ & $-6.291^{* * *}$ & $-6.322^{* * *}$ \\
GINI & -2.432 & -2.262 & -2.871 & -2.728 \\
$\Delta$ GINI & $-4.881^{* * *}$ & $-5.151^{* * *}$ & $-8.647 * * *$ & $-8.780^{* * *}$ \\
TOP & 0.825 & -1.290 & 0.491 & -2.368 \\
$\Delta$ TOP & $-4.306^{* * *}$ & $-4.849^{* * *}$ & $-9.299^{* * *}$ & $-10.227 * * *$ \\
FOP & $-2.727^{*}$ & $-3.807^{* *}$ & -2.430 & -2.848 \\
$\Delta$ FOP & $-3.203^{* *}$ & $-3.683^{* *}$ & $-3.893^{* * *}$ & $-4.178^{* * *}$ \\
\hline
\end{tabular}

Notes: $(* * *) 1 \%,(* *) 5 \%$ and $(*) 10 \%$ level of significance, respectively.

Table 4. Johansen cointegration test results (trace statistics, $k=2$ )

Model A (Financial development index: FS)

Endogenous variables: EG, FS; Weakly exogenous variables: GINI, TOP, FOP

Deterministic components: trend (restricted), SBGD (restricted)

\begin{tabular}{lll}
\hline Null & Alternative & Statistic \\
$r=0$ & $r>=1$ & $45.373^{* *}$ \\
$r<=1$ & $r=2$ & 14.993 \\
\hline
\end{tabular}

Model B (Financial development index: FE)

Endogenous variables: EG, FE; Weakly exogenous variables: GINI, TOP, FOP

Deterministic components: trend (restricted), SBGD (restricted)

$\begin{array}{lll}\frac{\text { Null }}{r=0} & \text { Alternative } & \text { Statistic } \\ r>=1 & 44.948^{* *} \\ r<=1 & r=2 & 18.166\end{array}$

Notes: (**) 5\% level of significance. The results are based on critical values simulated with 400 random walks and 2500 replications.

Table 5. Diagnostic test results

\begin{tabular}{lll}
\hline Test & Model A & Model B \\
\hline Autocorrelation & $2.042[0.728]$ & $1.855[0.762]$ \\
Normality & $6.153[0.188]$ & $3.707[0.447]$ \\
Heteroscedasticity & $15.134[0.653]$ & $9.823[0.938]$ \\
\hline
\end{tabular}

Notes: The results are based on $X^{2}$ statistics. For autocorrelation heteroscedasticity, LM(2) statistics are reported, and $p$-values are provided in parentheses. 


\subsection{Cointegrating Vectors}

The cointegrating vectors and " $\alpha$ " are given in Table 6 . " $\alpha$ " is the ECT (error correction term) coefficient that exhibits the speed of adjustment back to the long-run equilibrium whenever there is a deviation from the steady state in the cointegrating system; in this regard, the ECT coefficient needs to be statistically significant holding a negative sign. As reported in Table 6, all the ETC coefficients are statistically significant at the $10 \%$ level or better-given by the weakly exogenous test-together with acceptable sizes and negative signs. These indicate that a long-run steady-state is established in the models. Normalizing the coefficient of EG/FS/FE to one in the cointegrating vector, we have confirmed the direction of each underlying variable with respect to the three variables, that is, whether one variable is either positive or negative to economic growth/financial size/financial efficiency by looking at each variable's sign in the cointegrating vector.

Table 6. Cointegrating vectors

Model A (Financial development index: FS)

$E G=-0.246 F S+0.189$ GINI +0.217 TOP $-0.157 F O P+0.035$ Break +0.024 Trend

$\alpha=-0.215^{* * *}$

$F S=-4.058 E G+0.766 G I N I+0.880 T O P-0.639 F O P+0.143$ Break +0.098 Trend

$\alpha=-0.088^{* *}$

Model B (Financial development index: FE)

$E G=-0.278 F E-0.494 G I N I+0.256$ TOP $-0.187 F O P+0.042$ Break +0.012 Trend

$\alpha=-0.202 * * *$

$F E=-0.3 .596 E G-1.776 G I N I+0.922 T O P-0.672 F O P+0.152 B r e a k+0.043$ Trend

$\alpha=-0.070^{*}$

Notes: $(* * *) 1 \%,(* *) 5 \%$ and $(*) 10 \%$ level of significance, respectively. The significance of $\alpha$ (ETC coefficient) is given by the weakly exogeneity test.

\subsection{Causality Test Results}

Subsequently, the statistics of the strong exogeneity test are presented in Tables 7 and 8 whose third columns show the direction of impact given by checking the sign of each underlying variable in the cointegrating vector (see Table 6). First of all, referring to the results of model A whose financial development index is FS, we identify a negative unilateral causality from financial size to economic growth. Similarly, the results of model B, in which financial development is proxied by FE, show a one-way causality from financial efficiency to economic growth which is also negative. Although these findings are different from a standard observation of finance enhancing economic growth, it is likely in the present VECM framework in which three weakly exogenous variables are incorporated. In particular, the Gini coefficient-the income distribution index-might be influential for the finance-growth nexus in India where both pursuing economic growth and creating a more egalitarian society are equally important policy objectives.

On the other hand, we also need to look at the impact of each weakly exogenous variable either on economic growth or on financial development. The Gini coefficient has a positive impact on economic growth and financial size in model A, whereas it is negative for economic growth and financial efficiency in model B. Thus, so long as financial development is measured by its size, improving income distribution seems to be good for economic growth; however, it is not so if we consider financial efficiency. As far as the impact of trade openness is concerned, while it promotes both economic growth and financial size in model A, no significant result is found out in model B. Finally, financial openness is negative for economic growth both in models $\mathrm{A}$ and $\mathrm{B}$, but there is no evidence of financial openness influencing financial development. 
Table 7. Causality test results of Model A

$H_{0}$ : Financial size/Gini coefficient/Trade openness/Financial openness does not cause economic growth.

Regressors

FS \& ECT(-1)

GINI \& ECT(-1)

TOP \& ECT(-1)

FOP \& ECT(-1)
Result

$\operatorname{CHSQ}(2)=7.495 * *$

$\operatorname{CHSQ}(2)=6.159 * *$

$\mathrm{CHSQ}(2)=5.038 *$

$\operatorname{CHSQ}(2)=6.290 *$
Direction

Negative

Positive

Positive

Negative

$H_{0}$ : Economic growth/Gini coefficient/Trade openness/Financial openness does not cause financial size.

Regressors

EG \& ECT(-1)

GINI \& ECT(-1)

TOP \& ECT(-1)

FOP \& ECT(-1) $\underline{\text { Result }}$

$\operatorname{CHSQ}(2)=4.042$

$\operatorname{CHSQ}(2)=2.494$

$\mathrm{CHSQ}(2)=4.786 *$

$\operatorname{CHSQ}(2)=2.416$
Direction

Negative

Positive

Positive

Negative

Notes: (**) $5 \%$ and $(*) 10 \%$ level of significance, respectively.

Table 8. Causality test results of Model B

H0: Financial efficiency/Gini coefficient/Trade openness/Financial openness does not cause economic growth.

$\begin{array}{lll}\text { Regressors } & \underline{\text { Result }} & \text { Direction } \\ \text { FE \& ECT(-1) } & \text { CHSQ }(2)=6.117^{* *} & \text { Negative } \\ \text { GINI \& ECT(-1) } & \text { CHSQ }(2)=2.943 & \text { Negative } \\ \text { TOP \& ECT(-1) } & \text { CHSQ }(2)=2.954 & \text { Positive } \\ \text { FOP \& ECT(-1) } & \text { CHSQ }(2)=4.819^{*} & \text { Negative }\end{array}$

$H_{0}$ : Economic growth/Gini coefficient/Trade openness/Financial openness does not cause financial efficiency.

$\begin{array}{lll}\text { Regressors } & \underline{\text { Result }} & \text { Direction } \\ \text { EG \& ECT(-1) } & \text { CHSQ }(2)=3.019 & \text { Positive } \\ \text { GINI \& ECT(-1) } & \text { CHSQ }(2)=1.898 & \text { Negative } \\ \text { TOP \& ECT }(-1) & \text { CHSQ }(2)=3.811 & \text { Positive } \\ \text { FOP \& ECT }(-1) & \text { CHSQ }(2)=1.396 & \text { Positive }\end{array}$

Notes: $(* *) 5 \%$ and $(*) 10 \%$ level of significance, respectively.

\section{Conclusions}

Over the sample period 1951-2011, we examined India's finance-growth nexus by using the cointegration and VECM approach of Johansen (1988) with weakly exogenous variables of income inequality, trade openness and financial openness, and the structural break dummy. The prime discovery of our assessment is that both financial size and financial efficiency reduce economic growth. So the answer to the Patrick (1966) issue is "growth-retarding", that is, financial development unilateraly exhibits a negative impact on economic growth; it differs from other studies' findings in which the casual direction is detected as either "supply-leading" (e.g. Bhattacharya \& Sivasubramanian, 2003; Rousseau \& Vuthipadadorn, 2005) or "demand-following" (e.g. Fase \& Abma, 2003) or bilateral (e.g. Luintel \& Khan, 1999; Singh, 2008). Thus, we contribute to the literature by sheding a different light on the causal relationship between economic growth and financial development in India.

Why is India's finance-growth nexus growth-retarding? While globalization-proxied by trade openness and financial openness-progressively goes on, the eradication of poverty by ameliorating income inequality-proxied by the Gini coefficient-has remained as a major policy goal since India's independence. In addition, there is a fact that many commercial banks in India have been owned and so directly and strongly controlled by the government ${ }^{7}$. Here, the hypothesis of Körner and Schnabel (2010) is very relevant to our result. According to them, so long as the extent of a country's financial deepening is not sufficient, we are likely to see a negative effect of public ownership of banks on economic growth. Although such a case is not observed in all countries, public ownership is harmful only if a country has low financial development and low institutional quality. It is well-known that a number of credit programs are directed by the government for eliminating poverty in India; such programs are usually unprofitable and so unwelcome 
by banks. These facts might be associated with our result of financial development unfavorable for economic growth. Moreover, our estimates of the negative impacts of financial development and financial openness on economic growth seem to support the view that higher financial deepening coupled with higher external openness associates with higher vulnerability to international shocks, ultimately leading to a financial crisis that brings a crucial, negative impact on an economy. Indeed, India experienced a severe financial crisis in 1991 after the country was in the process of (partial) financial liberalization experiencing credit boom and high output growth over the late $1980 \mathrm{~s}^{8}$.

As the policy implication drawn from the present study, it is important for policy makers to recognize that finance does not always promote economic growth, considering how to convert the effect of financial development from "growth-retarding" to "growth-enhancing". To this end, the reforms of India's financial system in terms of both quantity and quality are essential otherwise the country will be exposed to more speculation due to the on-going globalization while the government is required to achieve the objective of creating more equal income distribution for social justice. Moreover, rationally expecting that the growth effect of finance is not negative in the process of economic development, it is interesting to conduct a non-linear assessment for India's finance-growth nexus in the future. By doing so, more validated estimates would be obtained, in particular a threshold at which the effect changes from positive/negative to negative/positive could be detected.

\section{Acknowledgements}

I am very grateful to my wife, Hidemi Fukuda, appreciating her daily support for my research and many other things.

\section{References}

Ang, J. B. (2010). Finance and Inequality: The Case of India. Southern Economic Journal, 76, 738-761. https://doi.org/10.4284/sej.2010.76.3.738

Beck, T., Demirgüç-Kunt. A., \& Levine, R. (2009). Financial institutions and markets across countries and over time: data and analysis. World Bank Policy Research Working Paper, 4943. Washington DC: World Bank.

Bhattacharya, P. C., \& Sivasubramanian, M. N. (2003). Financial development and economic growth in India: 1970-1971 to 1998-1999. Applied Financial Economics, 13, 925-929. https://doi.org/10.1080/0960310032000129590

Chandavarkar, A. (1992). Of finance and development: Neglected and unsettled questions. World Development, 20, 133-142. https://doi.org/10.1016/0305-750X(92)90142-I

Cheung, Y., \& Lai, K. (1993). Finite-sample sizes of Johansen's likelihood ratio tests for cointegration. Oxford Bulletin of Economics and Statistics, 55, 313-28. https://doi.org/10.1111/j.1468-0084.1993.mp55003003.x

Demetriades, P. O., \& Hussein, K. A. (1996). Does financial development cause economic growth?: Time-series evidence from 16 Countries. Journal of Development Economics, 51, 387-411. https://doi.org/10.1016/S0304-3878(96)00421-X

Elliott, G., Rothenberg, T. J., \& Stock, J. H. (1996). Efficient test for an autoregressive unit root. Econometrica, 64, 813-836. https://doi.org/10.2307/2171846

Engle, R. F., \& Granger, C. W. (1987). Co-integration and error correction: Representation, estimation, and testing. Econometrica, 55, 251-276. https://doi:10.2307/1913236.

Enisan, A. A., \& Olufisayo, A. O. (2009). Stock market development and economic growth: Evidence from seven sub-Sahara African countries. Journal of Economics and Business, 61, 162-171. https://doi.org/10.1016/j.jeconbus.2008.05.001

Fase, M. M. G., \& Abma, R. C. N. (2003). Financial environment and economic growth in selected Asian Countries. Journal of Asian Economics, 14, 11-21. https://doi.org/10.1016/S1049-0078(02)00237-3

Fukuda, T. (2012). Financial development, economic growth and financial crisis in Asian emerging economies. Research in Applied Economics, 4, 1-22. https://doi.org/10.5296/rae.v4i2.1429

Gries, T., Kraft, M., \& Meierrieks, D. (2009). Linkages between financial deepening, trade openness, and economic development: Causality evidence from Sub-Saharan Africa. World Development, 37, 1849-1860. https://doi.org/10.1016/j.worlddev.2009.05.008

Ibrahim, S., Abdullahi, A. B., Azman-Aaini, W. N. W., \& Rahman, M. A. (2017). Finance-growth nexus: Evidence based on new measures of finance. International Journal of Economics and Management, 11, 17 -29.

Johansen, S. (1988). Statistical analysis of cointegration vectors. Journal of Economic Dynamics and Control, 12, 231-254. https://doi.org/10.1016/0165-1889(88)90041-3

Johansen, S., Mosconi, R., \& Nielsen, B. (2000). Cointegration analysis in the presence of structural breaks in the 
deterministic trend. Econometrics Journal, 3, 216-249.

Johansen, S., \& Juselius, K. (1992). Some structural hypotheses in a multivariate cointegration analysis of purchasing power parity and uncovered interest parity for the UK. Journal of Econometrics, 53, 211-244. https://doi.org/10.1016/0304-4076(92)90086-7

Katircioglu, S. T., Kahyar, N., \& Benar, H. (2007). Financial development, trade and growth triangle: The case of India. International Journal of Social Economics, 34, 586-598. https://doi.org/10.1108/03068290710778615

King, R. G., \& Levine, R. (1993). Finance and growth: Schumpeter might be right. Quarterly Journal of Economics, 108, 717-737. https://doi.org/10.2307/2118406

Körner, T., \& Schnabel, I. (2010). Public ownership of banks and economic growth: The role of heterogeneity. CEPR Discussion Paper 8138. Washington DC: Centre for Economic Policy Research.

Lane, P. R., \& Milesi-Ferretti, G. M. (2007). The external wealth of nations mark II: Revised and extended estimates of foreign assets and liabilities, 1970-2004. Journal of International Economics, 73, 223-250. https://doi.org/10.1016/j.jinteco.2007.02.003

Lee, J., \& Strazicich, M. C. (2003). Minimum LM unit root test with two structural breaks. Review of Economics and Statistics, 85, 1082-1089. https://doi.org/10.1162/003465303772815961

Lee, J., \& Strazicich, M. C. (2004). Minimum LM unit root test with one structural break. Appalachian State University Working Paper. Boone, NC: Appalachian State University.

Levine, R., \& Zervos, S. (1998). Stock markets, banks and economic growth. American Economic Review, 88, 537-558.

Loayza, N. R., Rancière, R., Servén, L., \& Ventura, J. (2007). Macroeconomic volatility and welfare in developing countries: An introduction. World Bank Economic Review 21,343-357. https://doi.org/10.1093/wber/lhm017

Lucas, R. E. (1988). On the mechanics of economic development. Journal of Monetary Economics, 22, 3-42. https://doi.org/10.1016/0304-3932(88)90168-7

Luintel, K. B., \& Khan, M. (1999). A quantitative reassessment of the finance-growth nexus: Evidence from a multivariate VAR. Journal of Development Economics, 60, 381-405. https://doi.org/10.1016/S0304-3878(99)00045-0

McKinnon, R. I. (1973). Money and Capital in Economic Development. Washington DC: Brookings Institution.

Patrick, H. T. (1966). Financial development and economic growth in underdeveloped countries. Economic Development and Cultural Change, 14, 174-189. https://doi.org/10.1086/450153

Phillips, P. C. B., \& Perron, P. (1988). Testing for a unit root in time series regression. Biometrika, 75, 335-346. https://doi.org/10.2307/2336182

Robinson, J. (1952). The Rate of Interest and Other Essays. London, England: Macmillan.

Rousseau, P. L., \& Vuthipadadorn, D. (2005). Finance, investment and growth: Time series evidence from 10 Asian economies, Journal of Macroeconomics, 27, 1, 87-106. https://doi.org/10.1016/j.jmacro.2003.09.004

Schumpeter, J. A. (1911). The Theory of Economic Development. Oxford, England: Oxford University Press.

Sehrawat, M., \& Giri, A. K. (2015). Financial development and income inequality in India: An application of ARDL approach. International Journal of Social Economics, 42, 64-81. https://doi.org/10.1108/IJSE-09-2013-0208

Shaw, E. S. (1973). Financial Deepening in Economic Development. London, England: Oxford University Press.

Singh, T. (2008). Financial development and economic growth nexus: A time-series evidence from India. Applied Economics, 40, 1615-1627. https://doi.org/10.1080/00036840600892886

Tiwari, A. K., Shahbaz, M., \& Islam, F. (2013). Does financial development increase rural-urban income inequality? International Journal of Social Economics, 40, 151 - 168. https://doi.org/10.1108/03068291311283616

Toda, H. Y., \& Phillips, P. C. B. (1993). Vector autoregression and causality. Econometrica, 61, 1367-1393. https://doi.org/10.2307/2951647

Wachtel, P. (2011). The evolution of the finance growth nexus. Comparative Economic Studies, 53, 475-488. https://doi.org/10.1057/ces.2011.16 


\section{Notes}

Note 1. There are some skeptical views for the finance-growth linkage. For example, Chandavarkar (1992) argues that financial development and economic growth may evolve independently. According to Lucas (1988), the role of finance in economic growth is overemphasized by the growth literature.

Note 2. The leading evidence of the finance-growth nexus (finance $\rightarrow$ growth) has been drawn from cross-country studies. In case of addressing the "Patrick (1966)" issue, however, the cross-country approach is not appropriate as those studies estimate a single equation in which economic growth only is treated as a dependent variable.

Note 3. The choice of the two "banking" indexes for financial development is due to the fact that India's financial system is strongly bank-based. In addition, as compared with stock market indexes, banking ones are more available over a longer time period.

Note 4. Indeed, the episode that India experienced a severe financial crisis in 1991 is statistically identified by the LS test. And we consider that the 1991 crisis seems to exhibit a certain impact on India's finance-growth nexus.

Note 5. The PP test is an alternative to the ADF-GLS test as the former's residual variance is robust to autocorrelation.

Note 6. For the Johansen (1988) cointegration test, both trace and eigenvalue statistics are available though, we show the former only in order to look for more robust estimates (Cheung and Lai, 1993).

Note 7. In India, the nationalization of major commercial banks was implemented in 1969 and 1980.

Note 8. Severe financial crises were observed across the developing world as evidence of the devastating consequence brought about by rapid and excessive financial deepening (e.g., Mexico's 1994-95 crisis; the Asian 1997-98 crisis). As financial crises imposed large welfare costs on crisis-hit economies, potential welfare gains from reducing the risk of financial crisis must be enormous for developing countries (Loayza, Rancière, Servén, Ventura, 2007).

Appendix A. Underlying variables

\begin{tabular}{|c|c|}
\hline Underlying Variable & Description \\
\hline Gini coefficient (GINI) & $\begin{array}{l}\text { The Gini coefficient series are obtained from the latest versions of } \\
\text { UNU-WIDER's World Income Inequality Database and the World Bank's } \\
\text { Databank. There are some missing values which are supplemented by the } \\
\text { missing value analysis procedure. }\end{array}$ \\
\hline Economic growth (EG) & $\begin{array}{l}\mathrm{EG}=\log [(\mathrm{GDP} / \mathrm{GDF}) / \mathrm{POP}] \text { where GDP is gross domestic product (line } \\
99 \mathrm{~B}), \mathrm{GDF} \text { is GDP deflator (line 99bip) and POP is population (line 99Z). }\end{array}$ \\
\hline Financial size (FS) & $\mathrm{FS}=\log (\mathrm{PC} / \mathrm{GDP})$ where $\mathrm{PC}$ is private credit (line 32D). \\
\hline Financial efficiency (FE) & $\begin{array}{l}\mathrm{FE}=\log [\mathrm{PC} /(\mathrm{DD}+\mathrm{TD})] \text { where } \mathrm{DD} \text { is demand deposits (line } 24) \text { and } \mathrm{TD} \text { is } \\
\text { time deposits (line 25). }\end{array}$ \\
\hline Financial crisis $(\mathrm{FC})$ & $\begin{array}{l}\text { FC = ER + MTF (The elementary variables are merged by the principal } \\
\text { component method to make FC. See Appendix 2). }\end{array}$ \\
\hline Trade openness (TOP) & $\begin{array}{l}\text { TOP }=\log [(\mathrm{X}+\mathrm{I}) / \mathrm{GDP}] \text { where } \mathrm{X} \text { is exports (line } 70) \text { and } \mathrm{I} \text { is imports (line } \\
71) .\end{array}$ \\
\hline Financial openness (FOP) & $\begin{array}{l}\text { FOP = FRTM + FATM + FETM (The elementary variables are merged by } \\
\text { the principal component method to make FOP. See Appendix } 3 \text { ) }\end{array}$ \\
\hline
\end{tabular}

Note: All the "lines" refer to those of the International Financial Statistics (IFS). 
Appendix B. Elementary variables of financial openness

\begin{tabular}{ll}
\hline Elementary Variable & Description \\
\hline Foreign exchange reserve/money supply & FRTM $=\log (\mathrm{FR} / \mathrm{M})$ where FR is foreign exchange reserve (line 1D) \\
(FRTM) & and M is money supply (line 35L). \\
Commercial banks' net foreign assets/ money & FATM $=\log (\mathrm{FA} / \mathrm{M})$ where FA is commercial banks' net foreign assets \\
supply (FATM) & (line 31N). \\
Financial account plus net errors \& & FETM $=\log$ (FE/M) where FAE is financial account plus net errors \& \\
omissions/money supply (FETM) & omissions (lines 78BJD \& 78CAD). \\
\hline
\end{tabular}

Note: All the "lines" refer to those of the International Financial Statistics (IFS).

\section{Copyrights}

Copyright for this article is retained by the author(s), with first publication rights granted to the journal.

This is an open-access article distributed under the terms and conditions of the Creative Commons Attribution license which permits unrestricted use, distribution, and reproduction in any medium, provided the original work is properly cited. 